\title{
Isolation and Characterization of Sesquiterpenes from Stem Bark of Warburgia ugandensis Sprague
}

\author{
Teshome Gonfa Hordofa \\ Department of Chemistry, College of Natural and Computational Sciences, Haramaya University, Ethiopia \\ P. O. Box 138, Dire Dawa \\ Corresponding author \\ tashe2002@gmail.com, teshome.gonfa@haramya.edu.et
}

Manuscript received: 06 May, 2020. Revision accepted: 12 May, 2020. Published: 17 May, 2020.

\begin{abstract}
Warburgia ugandensis Sprague is one of the medicinal plants traditionally used to treat a number of diseases like asthma, cough, diarrhea, common cold, stomachache and toothache in Ethiopia. However, there is still insufficient information on the isolation and evaluation of bioactive compounds from this plant species. Extraction, purification and isolation of the stem bark of this plant by dichloromethane and chloroform as solvents afforded two sesquiterpenes; namely, WU-1 (ugandensidial) and WU-2 (cinnamolide-3 $\beta$-acetate) respectively. The structural elucidations of these bioactive compounds were accomplished by using a variety of spectroscopic methods (IR, UV and NMR). The spectroscopic results compared with the reported data in the literature.
\end{abstract}

Keywords: Medicinal plants; Natural products; Sesquiterpenes; Warburgia ugandensis Sprague.

\section{INTRODUCTION}

Natural products extracted from medicinal plants are the major sources of modern drugs that have been used for treatment of human pathogens (Sasidharan et al., 2011). The studies of these medicinal plants were the basis of earliest medicines. Plant derived medicines constitute a substantial component of present day human healthcare systems (Gómez et al., 2007, Butle 2004). According to World Health Organization (WHO), more than $60 \%$ of the world's population and over $80 \%$ of the people in low incoming/developing countries depend upon traditional medicine for their primary health care needs (Sukirtha et al., 2012).

In recent years, medicinal plants as natural products have attracted attention due to their important bioactive content such as terpens, alkaloids, anthraquinones, steroids, tannins, glycosides, saponins, volatile oils, resins, phenols and flavonoids that are deposited in their different parts (Saiprasanna et al., 2012). The medicinal value of these plants also depends on bioactive phytochemical constituents that produce a definite physiologic action on the human body (Mohammed, 2018).

The genus Warburgia is one of the flowering plants belongs to Canellaceae family (Rabe et al., 2000). The four species of Warburgia namely, Warburgia elongate Verdc, Warburgia salutaris (Bertol. f.) Chiov., Warburgia stuhlmannii Engl. and Warburgia ugandensis Sprague are distributed restrictly in the eastern and southern Africa (Maroyi, 2013; Muchugi et al., 2008).

Warburgia ugandensis Sprague is highly aromatic evergreen trees that has restricted distributions in the evergreen forests (Rabe et al., 2000; Drage et al., 2014) and widely used as traditional medicinal plant in many parts of East Africa (Kenya, Uganda and Ethiopia) (Drage et al., 2014, Rajab et al., 2000). The plant is known with different names: East African green wood, East African green heart, East African pepper bark tree, Kenya green heart, green heart, pepper-bark tree (English) (Maundu et al., 2005; Wube et al., 2005), Zogdom (Wube et al., 2005) or Kenaffa (Amharic) (Dagne et al., 2009) and Befti (Oromo language).

The stem bark and roots have been used for the treatment of various diseases such as diarrhea, cough, common cold, general muscular pains, internal wounds, loss of appetite, malaria, syphilis, gonorrhea, stomachache, toothache, colds, throat and chest infections, fever, weak joints and general body pains (Rabe et al., 2000, Dharan et al., 2008). The compounds isolated from this plant also possess antifeedant, antibacterial, antifungal, anti-mycobacterial, cytotoxic (Rabe et al., 2000, Rajab et al., 2000) anti-plasmodial, anti-trypanosomal (Wube et al., 2010) anti-asthmatic (Karani et al., 2013) and antileishmanial activities (Ngure et al., 2009). However, the leaves of plant has weaker property compared to the stem bark and roots (Mbwambo et al., 2009). In Ethiopia, particularly in Bale zone, stem bark of this plant is traditionally used 
for treatment of a wide range of diseases, such as stomachache, toothache, malaria, tuberculosis, gonorrhea, asthma (Wube et al., 2010, Wube et al., 2005), cough and rabies (Geyid et al., 2005). It is also used to remove tapeworm from human body.

Many drimane and coloratane sesquiterpenes was isolated from the stem barks of Warburgia ugandensis Sprague. Some of these include waburganal (1), polygodial (2) (Kioy et al., 1990; Xu et al., 2009), mukaadial (3), warburgin (4) warburgiadione (5) (Wube et al., 2005; Kioy et al., 1990; Xu et al., 2009), pereniporin B (6) (Rajab et al., 2000), cinnamolide (7), cinnamolide-3 $\beta$-acetate (8), ugandensolide (9) (Wube et al., 2005; Xu et al., 2009), dendocarbin A (10), ugandenial A (11), 9 $\alpha, 11 \alpha$-dihydroxy, 6 $\beta$-acetylcinnamolide (12), dendocarbin L (13), dendocarbin M (14), 9 $\alpha$-hydroxycinnamolide (15) (Xu et al., 2009), muzigadial (16), muzigadiolide (17) (Wube et al., 2005; Kioy et al., 1990; Rukutt et al., 2005), 4(13),7coloratadien-12,11-olide (18), 6 $\alpha, 9 \alpha$-dihydroxy-4(13),7coloratadien-11,12-dial (19)and 7 $\beta$-hydroxy-4(13),8coloratadien-11,12-olide (20), 7 $\alpha$-hydroxy-8-drimen11,12-olide (21) (Wube et al., 2005), cinnamolide-3 $\beta$-ol (22), deacetylugandensolide (23) (Xu et al., 2009), $11 \alpha-$ hydroxymuzigadiolide (24) (Rajab et al., 2000; Wube et al., 2005), ugandensidial (25) (Rajab et al., 2000; Wube et al., 2005; Kioy et al.,1990).

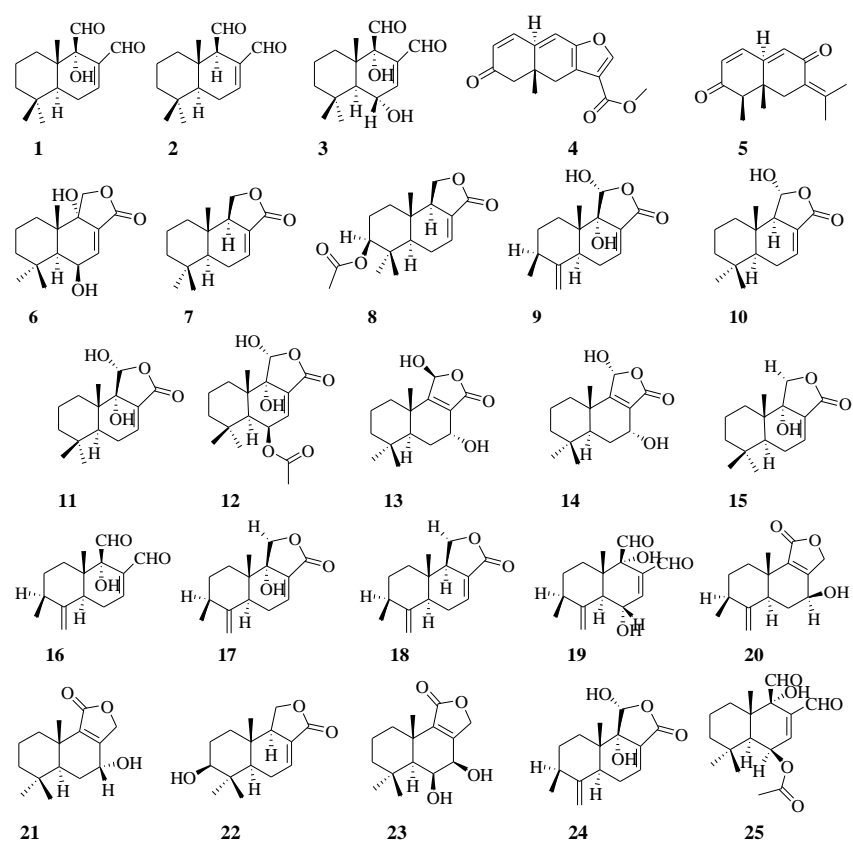

Figure 1. Drimane and colorotane sesquiterpenes isolated from stem bark of Warburgia ugandensis Sprague.

Many of sesquiterpenes have been extracted and isolated from this plant species. Despite of its medicinal uses, but still, extraction, isolation then characterization of active compounds from this medicinal plant is not sufficient. These, therefore, give emphasis on the choice of appropriate solvents and selection of the plant part (stem bark) to isolate the phytochemical constituents and characterize with very visible spectroscopic data.

\section{MATERIALS AND METHODS}

\section{Experimental materials}

Freshly stem bark of Warburgia ugandensis Sprague (Canellaceae) was collected from Barbere wareda, Bale zone, South Eastern part of Ethiopia. The plant was then shade-dried at room temperature for one month. The dried stem barks were crushed to fine powder using an electrical grinder.

Chloroform, dichloromethane, EtOH, petroleum ether, n-hexane, deuterated chloroform $\left(\mathrm{CDCl}_{3}\right)$ were used. Analytical TLC was performed using $20 \times 20 \mathrm{~cm}$, $0.20 \mathrm{~mm}$ thick silica gel 60 with fluorescent indicator $\mathrm{UV}_{254}$ to determine the number of components in a mixture and the purity of compounds. Kieselgel 40*, particle size of $0.063-0.200 \mathrm{~mm}$ and 70-230 mesh ASTM silica gel was used for column chromatography. Compounds on TLC were first detected by Ultraviolet lamp, multiband 254/366 $\mathrm{nm}$ and then sprayed with $1 \%$ vanillin in sulfuric acid.

Heidolph rotary evaporator was used for removal of solvent under reduced pressure. Melting points were determined by using Stuart SMP3 melting point apparatus. UV/Vis spectra were recorded on GENESY'S 2PC UV-Vis scanning spectrometer $(200-800 \mathrm{~nm})$ in $\mathrm{CH}_{3} \mathrm{CN}$. The $1 \mathrm{D}\left({ }^{1} \mathrm{H}\right.$ at 400.13 and ${ }^{13} \mathrm{C}$ at $\left.100.6 \mathrm{MHz}\right)$ were recorded on a Bruker Advance 400 spectrometer in $\mathrm{CDCl}_{3}$. The residual proton signal of the solvent is used as reference. IR spectra were recorded with $\mathrm{KBr}$ pellets on Perkin Elmer Bx Infrared Spectrometer in the range 400- $4000 \mathrm{~cm}^{-1}$. Optical rotations were measured on Autopol IV automatic polarimeterat $20^{\circ}$ in $\mathrm{CHCl}_{3}$.

\section{Experimental procedures}

The air-dried and finely powdered stem bark (100 g) was soaked and extracted successively with $600 \mathrm{~mL}$ of n-hexane, dichloromethane and chloroform for 48hours. Each extract was filtered and the solvent was removed by rotary evaporator under reduced pressure.

The crude dichloromethane extract (5.5 g) was subjected to column chromatography on a silica gel using n-hexane $(100 \%)$ as eluent. Out of 25 fractions collected, fractions 11 and 12 were combined, concentrated and further fractionated over a silica gel column using n-hexane/EtOAc 85:15 as eluent. Fractions 6 and 7 which showed a single spot with same $\mathrm{Rf}$ value were combined and concentrated to give $21 \mathrm{mg}$ of white solid. The compound was coded as WU-1.

The crude chloroform extract (1.93 g) was applied on a column silica gel using $100 \%$ hexane as mobile phase. Fractions 11-15 were combined, concentrated and further purified on silica gel column using nhexane/EtOAc 70:30. Fractions 10 and 11 showed a 
single spot with the same $\mathrm{Rf}$ value and were combined and concentrated to afford $44 \mathrm{mg}$ of white solid. The compound was labeled as WU-2.

\section{RESULTS AND DISCUSSIONS}

\section{Characterization of compound WU-1}

WU-1 was isolated as a white crystalline solid with melting point of $131-134^{\circ} \mathrm{C}$ and $\mathrm{Rf}$ value 0.34 using $\mathrm{n}$ hexane: ethyl acetate $(3: 2)$ as a solvent system. WU-1 was reacted with 2,4-dinitrophenylhydrazine (DNP) in ethanol and $\mathrm{H}_{2} \mathrm{SO}_{4}$ gave yellow precipitate indicating the presence of carbonyl groups in the compound. The optical rotation $\left([\alpha]_{\mathrm{D}}{ }^{20}, \mathrm{CHCl}_{3}\right)$ of $\mathbf{W U - 1}$ measured to be $-197^{\circ}$ indicating that the compound is optically active. The $\mathrm{UV}\left(\mathrm{CH}_{3} \mathrm{CN}\right)$ spectrum (Figure 2) showed maximum absorption $\left(\lambda_{\max }\right)$ at $220 \mathrm{~nm}$ indicating the presence of unsaturated group in the compound.

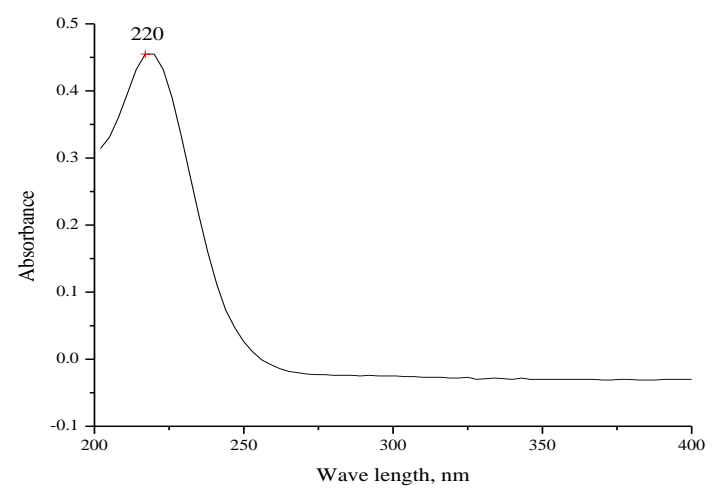

Figure 2. UV-Visible spectrum of WU-1.

The IR spectrum (Figure 3) displayed strong absorption band at $3431 \mathrm{~cm}^{-1}$ due to vibrational stretching of O-Hgroup. Absorption band at $2926 \mathrm{~cm}^{-}$ ${ }^{1}$ indicated the presence of $\mathrm{C}-\mathrm{H}$ stretching of saturated group. IR spectrum demonstrated, in addition to strong absorption bands at 1744 and $1721 \mathrm{~cm}^{-1}$ due toester carbonyl and aldehyde, the presence of olefinic group at $1693 \mathrm{~cm}^{-1}$.

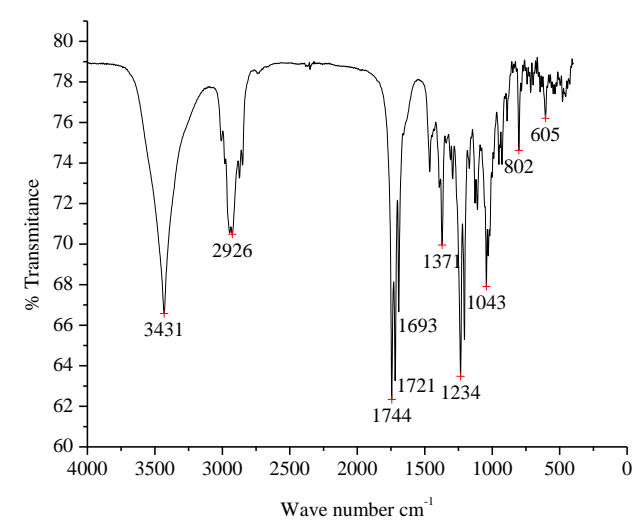

Figure 3. IR spectrum of WU-1.

The ${ }^{1} \mathrm{H}$ NMR spectrum (Figure 4 and Table 1) demonstrated a doublet at $\delta 9.78$ and a singlet at $\delta 9.5$ each integrating for one proton due to two aldehyde protons. The doublet at $\delta 7.03$ integrating for one proton corresponded to anolefinic proton. The triplet at $\delta 5.92$ which integrated for one proton is due to a proton on a methine carbon attached to an electronegative atom whereas the peak at $\delta 4.10$ indicated the presence of $\mathrm{OH}$ group. The spectrum also showed a singlet at $\delta 2.16$ due to an acetyl methyl group and three methyl groups at $\delta$ $1.35,1.18$ and 1.04 attached to quaternary carbon atoms.

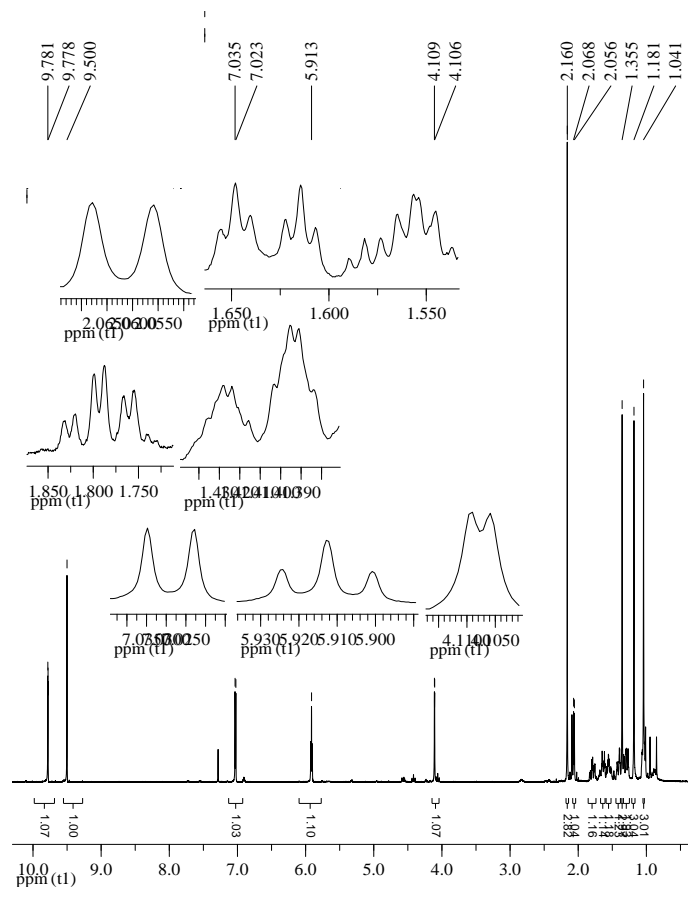

Figure 4. ${ }^{1} \mathrm{H}$ NMR spectrum of WU-1.

The ${ }^{13} \mathrm{C}$ NMR spectrum (Figure 5 of WU-1 showed well-resolved resonances of the 17 carbon atoms. The ${ }^{13} \mathrm{C}$ NMR and the DEPT135 (Figure 6 and Table 2) spectra displayed four quaternary carbons, one ester carbonyl carbon ( $\delta 170.09)$, three methine carbons, two aldehyde carbonyl carbons ( $\delta 201.17$ and 193.08), three methylene carbons and four methyl carbons.

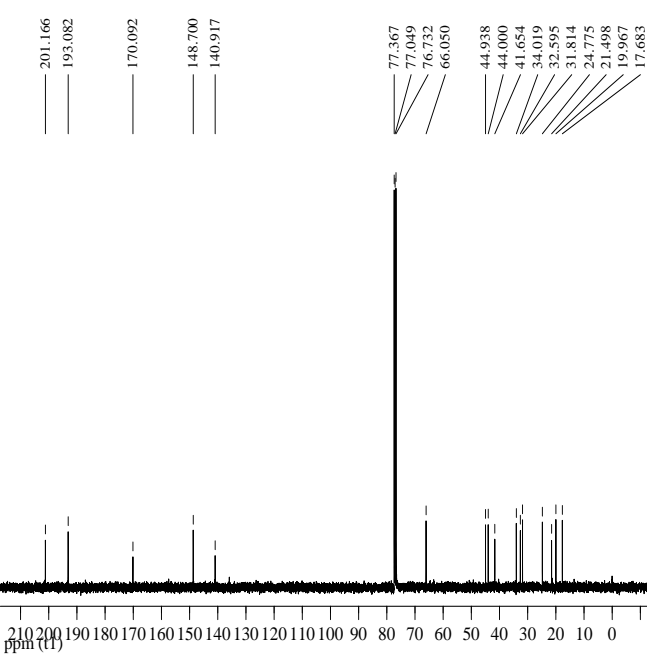

Figure 5. ${ }^{13} \mathrm{C}$ NMR spectrum of WU-1. 


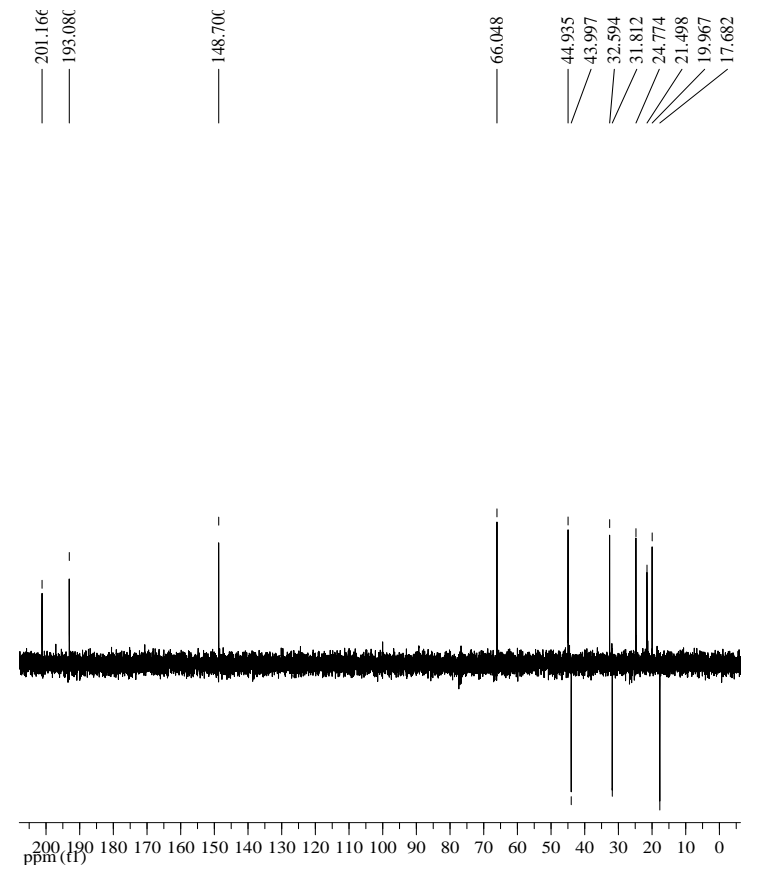

Table 1. Proton decoupled ${ }^{13} \mathrm{C}$ NMR and DEPT $135\left(100.6 \mathrm{MHz}, \mathrm{CDCl}_{3}\right)$ spectroscopic data of WU-1.

\begin{tabular}{|c|c|c|c|}
\hline $\begin{array}{l}\text { Carbons } \\
\text { No. }\end{array}$ & $\begin{array}{l}{ }^{13} \mathrm{C} \text { NMR } \delta \\
(\mathrm{ppm})\end{array}$ & $\begin{array}{l}\text { DEPT } 135 \delta \\
(\mathrm{ppm})\end{array}$ & Remark \\
\hline $\mathrm{C}-1$ & 31.81 & 31.81 & $\mathrm{CH}_{2}$ \\
\hline $\mathrm{C}-2$ & 17.68 & 17.68 & $\mathrm{CH}_{2}$ \\
\hline $\mathrm{C}-3$ & 44.00 & 44.00 & $\mathrm{CH}_{2}$ \\
\hline $\mathrm{C}-4$ & 34.02 & - & $\mathrm{C}$ (Quaternary carbon) \\
\hline $\mathrm{C}-5$ & 44.94 & 44.94 & $\mathrm{CH}$ \\
\hline C-6 & 66.05 & 66.05 & $\mathrm{CH}$ \\
\hline $\mathrm{C}-7$ & 148.70 & 148.70 & $\mathrm{CH}$ \\
\hline $\mathrm{C}-8$ & 140.92 & - & $\mathrm{C}$ (Quaternary carbon) \\
\hline \multicolumn{4}{|r|}{ 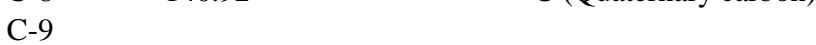 } \\
\hline $\mathrm{C}-10$ & 41.65 & - & C (Quaternary carbon) \\
\hline $\mathrm{C}-11$ & 201.17 & 201.17 & $\mathrm{CH}$ \\
\hline $\mathrm{C}-12$ & 193.08 & 193.08 & $\mathrm{CH}$ \\
\hline $\mathrm{C}-13$ & 32.60 & 32.60 & $\mathrm{CH}_{3}$ \\
\hline $\mathrm{C}-14$ & 24.77 & 24.77 & $\mathrm{CH}_{3}$ \\
\hline $\mathrm{C}-15$ & 19.97 & 19.97 & $\mathrm{CH}_{3}$ \\
\hline $\mathrm{CH}_{3} \mathrm{CO}$ & 21.50 & 21.50 & $\mathrm{CH}_{3}$ \\
\hline $\mathrm{CH}_{3} \mathrm{CO}$ & 170.09 & - & $\mathrm{C}$ (Quaternary carbon) \\
\hline
\end{tabular}

Figure 6. DEPT 135 spectrum of WU-1.

The ${ }^{1} \mathrm{H}$ and ${ }^{13} \mathrm{C}$ NMR results obtained for WU-1 were comparable with ${ }^{1} \mathrm{H}$ NMR (Kioy et al., 1990) and ${ }^{13} \mathrm{C}$ NMR (Rukutt et al., 2005) spectral data of ugandesidial (25) (Table 2).

Table 2. Comparison of ${ }^{1} \mathrm{H}\left(400.13, \mathrm{MHz}, \mathrm{CDCl}_{3}\right)$ and ${ }^{13} \mathrm{C} \mathrm{NMR}\left(100.6 \mathrm{MHz}, \mathrm{CDCl}_{3}\right)$ spectroscopic data of WU-1 and ugandensidial (25).

\begin{tabular}{|c|c|c|c|c|}
\hline \multirow{2}{*}{$\begin{array}{l}\text { Position } \\
\text { of } \\
\text { carbons }\end{array}$} & \multicolumn{2}{|l|}{ WU-1 } & \multicolumn{2}{|c|}{ Ugandensidial } \\
\hline & $\delta{ }^{13} \mathrm{CNMR}$ & $\begin{array}{l}{ }^{1} \text { HNMR } \delta \text { (ppm) } \\
\text { (Multiplicity, Integration) }\end{array}$ & $\delta{ }^{13} \mathrm{CNMR}$ & $\begin{array}{l}{ }^{1} \text { HNMR } \delta(p p m) \\
\text { (Multiplicity, Integration) }\end{array}$ \\
\hline $\mathrm{C}-1$ & 31.81 & $1.83-1.76(2 \mathrm{H}, \mathrm{m})$ & 32.02 & - \\
\hline $\mathrm{C}-2$ & 17.68 & $1.65-1.55(2 \mathrm{H}, \mathrm{m})$ & 17.88 & - \\
\hline $\mathrm{C}-3$ & 44.00 & $1.43-1.40(1 \mathrm{H}, \mathrm{m}) 1.33(1 \mathrm{H}, \mathrm{m})$ & 44.21 & - \\
\hline C-4 & 34.02 & - & 34.21 & - \\
\hline $\mathrm{C}-5$ & 44.94 & $2.09(1 \mathrm{H}, \mathrm{d}, \mathrm{J}=4.8 \mathrm{~Hz})$ & 45.16 & $2.04(1 \mathrm{H}, \mathrm{d}, \mathrm{J}=4.7 \mathrm{~Hz}$ \\
\hline C-6 & 66.05 & $5.92(1 \mathrm{H}, \mathrm{t}, \mathrm{J}=4.8 \mathrm{~Hz})$ & 66.26 & $5.89(1 \mathrm{H}, \mathrm{t}, \mathrm{J}=4.7 \mathrm{~Hz})$ \\
\hline C-7 & 148.70 & $7.03(1 \mathrm{H}, \mathrm{d}, \mathrm{J}=4.8 \mathrm{~Hz})$ & 148.86 & $7.00(1 \mathrm{H}, \mathrm{d}, \mathrm{J}=4.7 \mathrm{~Hz}$ \\
\hline C-8 & 140.92 & - & 141.14 & - \\
\hline C-9 & - & $4.10(1 \mathrm{H}, \mathrm{d}, \mathrm{J}=1.2 \mathrm{~Hz})$ & - & $4.10(1 \mathrm{H}, \mathrm{d}, \mathrm{J}=1.4 \mathrm{~Hz})=1.4 \mathrm{~Hz}, 9-\mathrm{OH})=1.4 \mathrm{~Hz}, 9-\mathrm{OH})$ \\
\hline $\mathrm{C}-10$ & 41.65 & - & 41.85 & - \\
\hline C-11 & 201.17 & $9.78(1 \mathrm{H}, \mathrm{d}, \mathrm{J}=1.2 \mathrm{~Hz})$ & 201.32 & $9.76(1 \mathrm{H}, \mathrm{d}, \mathrm{J}=1.4 \mathrm{~Hz}$ \\
\hline $\mathrm{C}-12$ & 193.08 & $9.5(1 \mathrm{H}, \mathrm{s})$ & 193.24 & $9.48(1 \mathrm{H}, \mathrm{s})$ \\
\hline C-14 & 24.77 & $1.18(3 \mathrm{H}, \mathrm{s})$ & 24.96 & $1.17(3 \mathrm{H}, \mathrm{s}$ \\
\hline C-15 & 19.97 & $1.35(3 \mathrm{H}, \mathrm{s})$ & 20.15 & $1.34(3 \mathrm{H}, \mathrm{s})$ \\
\hline $\mathrm{CH}_{3} \mathrm{CO}$ & 21.50 & $2.16(3 \mathrm{H}, \mathrm{s})$ & 21.67 & $2.14(3 \mathrm{H}, \mathrm{s})$ \\
\hline $\mathrm{CH}_{3} \mathrm{CO}$ & 170.09 & - & 170.27 & - \\
\hline
\end{tabular}

In addition, the melting point of $\mathbf{W U}-\mathbf{1}\left(131-134^{\circ} \mathrm{C}\right)$ was in good agreement with the reported melting point of ugandensidial $\left(138-140^{\circ} \mathrm{C}\right)$ (Xu et al., 2009). Based on the above data and in comparison with the literature (Kioy et al., 1990), WU-1 (Figure 7) is most probably ugandensidial.
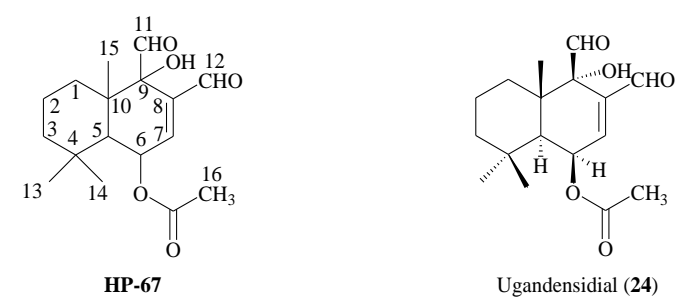

Figure 7. The structure of WU-1 and ugandensidial (24). 


\section{Characterization of compound WU-2}

WU-2 was obtained as a white crystalline solid (melting point $155-157^{\circ} \mathrm{C}$ ) with $\mathrm{Rf}$ value 0.41 using n-hexane: ethyl acetate (3:2) as solvent systems. It is optically active with optical rotation $\left([\alpha]_{\mathrm{D}}{ }^{20},\left(\mathrm{CHCl}_{3}\right)+16\right.$. An absorption maximum $\left(\lambda_{\max }\right)$ at $221 \mathrm{~nm}$ in the $\mathrm{UV}$ $\left(\mathrm{CH}_{3} \mathrm{CN}\right)$ spectrum (Figure 8) was characteristic of a molecule possessing an unsaturated lactone structure.

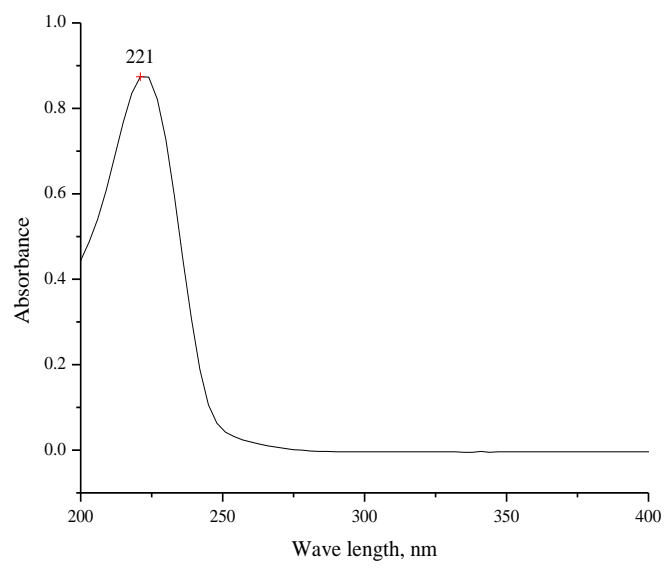

Figure 8. UV-Visible spectrum of WU-2.

The IR(KBr) spectrum (Figure 9) displayed an absorption band at $3439 \mathrm{~cm}^{-1}$ due to the stretching vibration of $\mathrm{O}-\mathrm{H}$ group whereas absorption bands at $2969 \mathrm{~cm}^{-1}$ and $2914 \mathrm{~cm}^{-1}$ demonstrated $\mathrm{C}-\mathrm{H}$ stretching vibration of alkane. Strong absorption bands at $1760 \mathrm{~cm}^{-}$ 1 and $1680 \mathrm{~cm}^{-1}$ showed the presence of an $\alpha, \beta$ unsaturated carbonyl group while absorption band at $1731 \mathrm{~cm}^{-1}$ indicated the presence of ester carbonyl group. The strong absorption bands at $1246 \mathrm{~cm}^{-1}$ and $1197 \mathrm{~cm}^{-1}$ demonstrated C-O stretching.

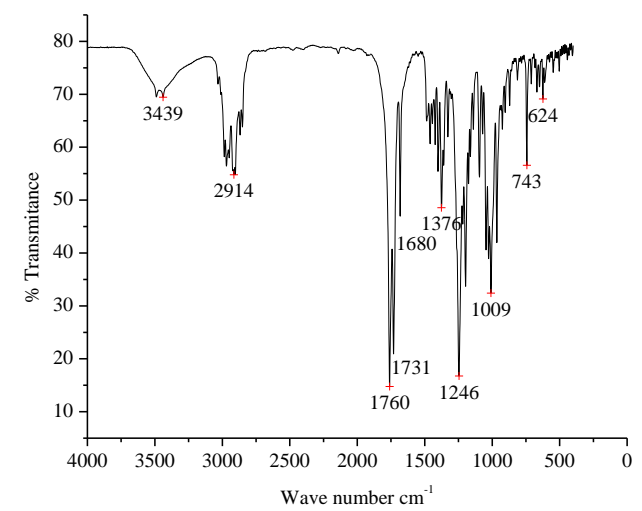

Figure 9. IR spectrum of WU-2

The quartet at $\delta 6.9$ observed in the ${ }^{1} \mathrm{H}$ NMR spectrum (Figure 10 and Table 4) of WU-2 integrating for one proton corresponded to an olefinic proton attached to C-7. The tripletsat $\delta 4.41$ and 4.05 integrated for one protoneach due to oxymethyleneprotons on C11. The doublet of doubletat $\delta 4.57$ which integrated for one proton indicated oxymethine proton attached to C-3. The ${ }^{1} \mathrm{H}-\mathrm{NMR}$ spectrum also showed three methyl protons signals at $\delta 1.00(3 \mathrm{H}, \mathrm{s}), 0.93(3 \mathrm{H}, \mathrm{s})$ and 0.84
$(3 \mathrm{H}, \mathrm{s})$ whereas the acetate methyl protons appeared at $\delta$ 2.08 .

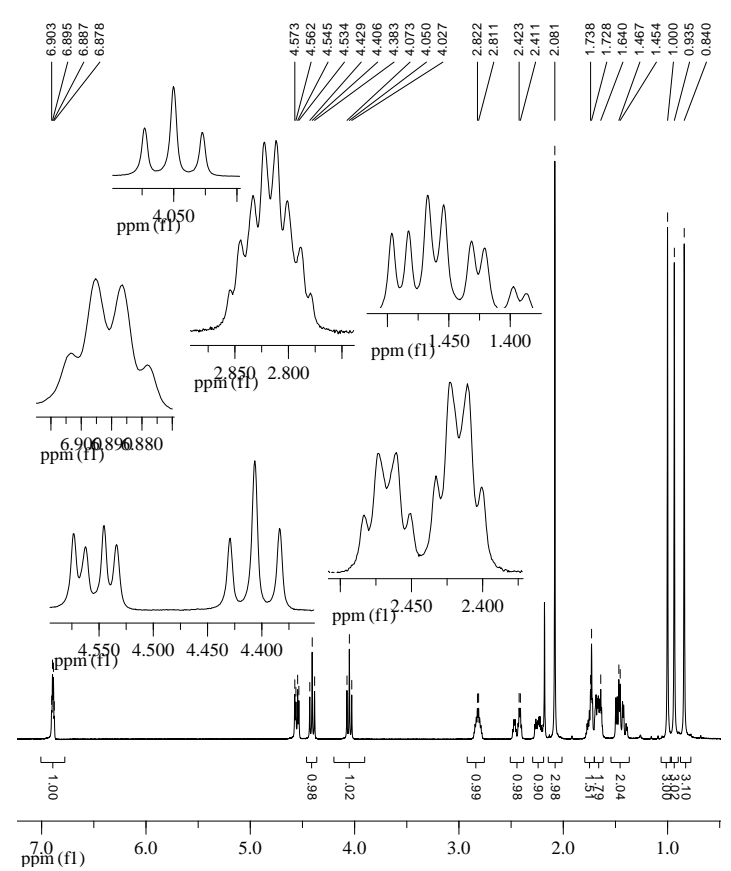

Figure 10. ${ }^{1} \mathrm{H}$ NMR spectrum of WU-2

The ${ }^{13} \mathrm{C}$ NMR (Figure 11) and DEPT135 experiments (Figure $\mathbf{1 2}$ and Table 3) displayed 17 carbon atom resonances comprising of two carbonyl carbons $(\delta 169.81$ and 170.79$)$, three quaternary carbons $(\delta 34.01,37.63$ and 127.16$)$, four methine $(\delta 49.28$, 50.57 , oxymethine $\delta 80.13$ and olefinic methine $\delta$ $135.82)$, four methylene $(\delta 23.52,24.65,36.67$ and oxygenated methylene $\delta$ 66.95) four methyl carbons $(\delta 13.49,15.99,21.23$ and 27.80).

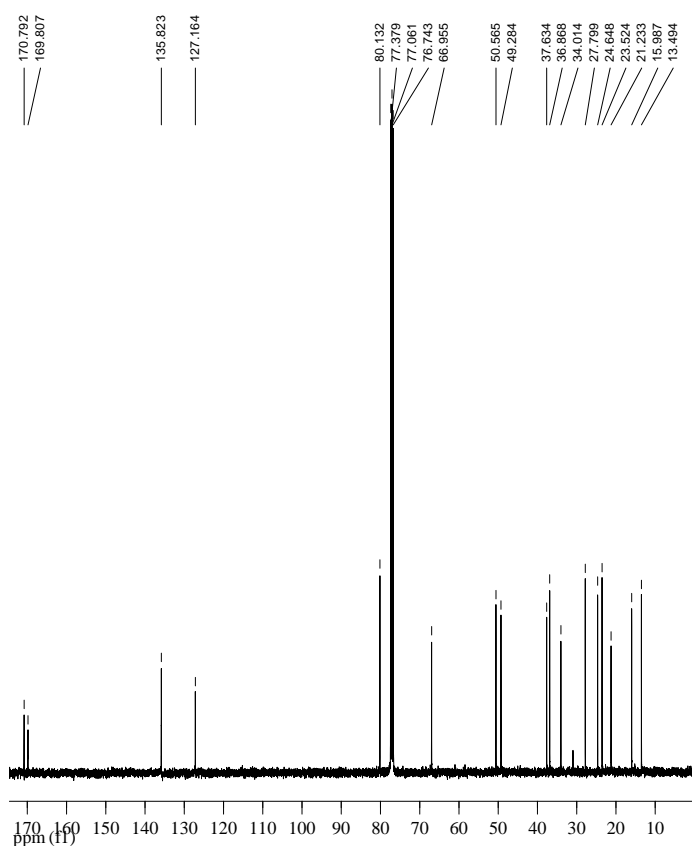

Figure 11. ${ }^{13} \mathrm{C}$ NMR spectrum of WU-2. 


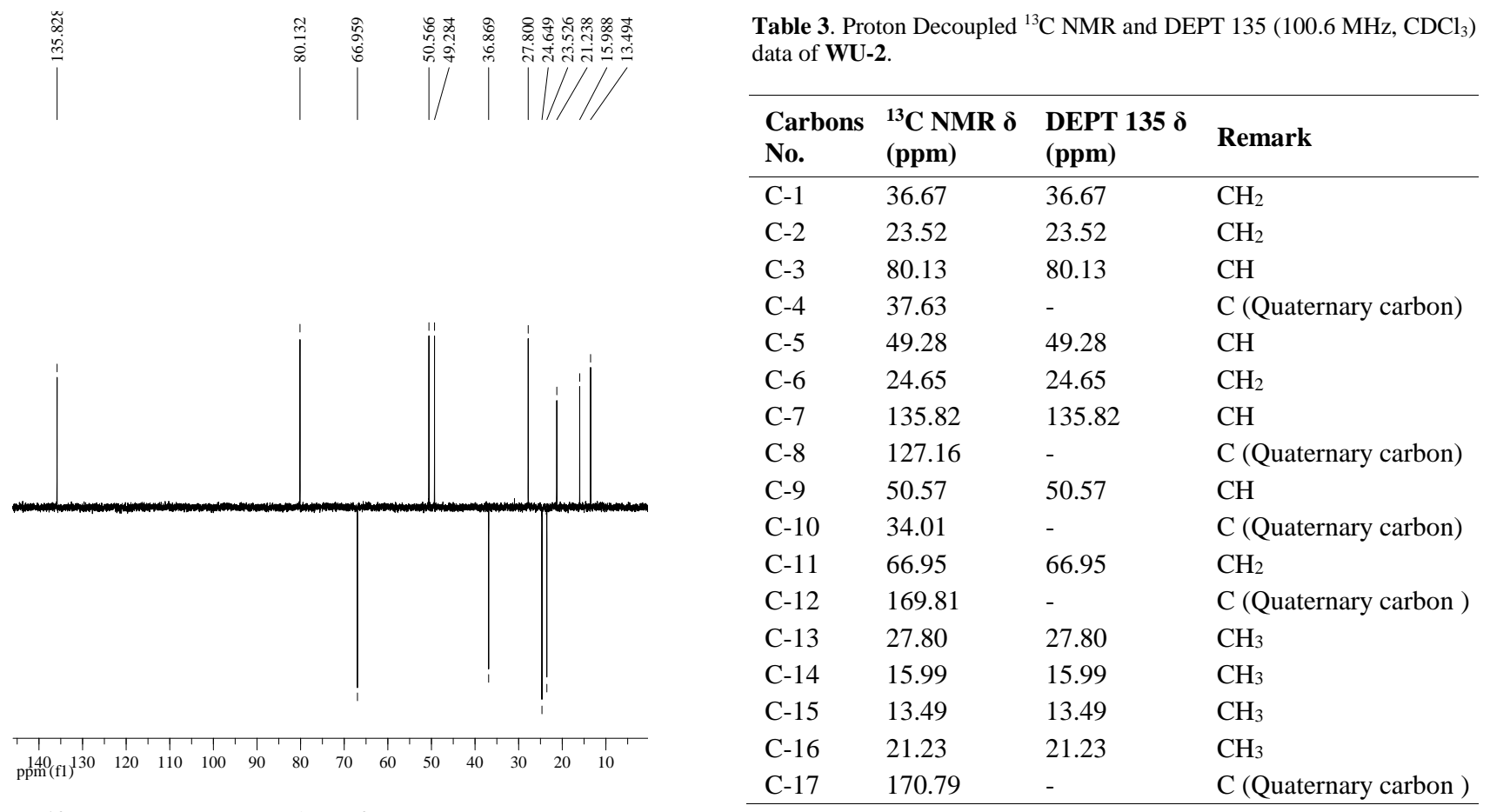

Figure 12. DEPT 135 spectrum of WU-2.

The ${ }^{1} \mathrm{H}$ NMR and ${ }^{13} \mathrm{C}$ NMR data obtained for WU-2 are comparable with data obtained for cinnamolide-3 $\beta$-acetate (8) (isolated and identified from the same plant) in the literature (Wube et al., 2005). Moreover, the melting point of WU-2 $\left(155-157^{\circ} \mathrm{C}\right)$ and cinnamolide-3 $\beta$-acetate $\left(153-157^{\circ} \mathrm{C}\right)$ (Kioy et al., 1990) are comparable.

Table 4. Comparison of ${ }^{1} \mathrm{H}(400.13, \mathrm{MHz}, \mathrm{CDCl} 3)$ and ${ }^{13} \mathrm{C}-\mathrm{NMR}\left(100.6 \mathrm{MHz}, \mathrm{CDCl}_{3}\right)$ spectral data of $\mathbf{W U}-\mathbf{2}$ with those of cinnamolide-3 $\beta$-acetate $(\mathbf{8})$.

\begin{tabular}{|c|c|c|c|c|}
\hline \multirow{2}{*}{$\begin{array}{l}\text { Carbons } \\
\text { No. }\end{array}$} & \multicolumn{2}{|c|}{ Observed NMR data of HP-81(ppm) } & \multicolumn{2}{|c|}{ 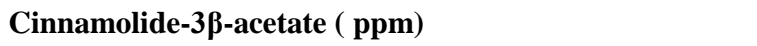 } \\
\hline & $\delta^{13} \mathrm{C}$ NMR & $\delta^{1} \mathrm{HNMR}(\mathrm{ppm})$ (Multiplicity,Integration) & $\delta^{13} \mathrm{C}$ NMR & $\delta^{1} \mathrm{HNMR}(\mathrm{ppm})$ (Multiplicity, Integration) \\
\hline \multirow[t]{2}{*}{1} & 36.67 & $1.42(1 \mathrm{H}, \mathrm{ddd}, \mathrm{J}=13.6,4 \mathrm{~Hz})$ & 36.9 & $1.42(1 \mathrm{H}, \mathrm{ddd}, \mathrm{J}=13.5,4.0 \mathrm{~Hz}, \alpha)$ \\
\hline & & $1.65(1 \mathrm{H}, \mathrm{td}, \mathrm{J}=11.6,5.2 \mathrm{~Hz})$ & & $1.64(1 \mathrm{H}, \mathrm{dt}, \mathrm{J}=13.5,3.5 \mathrm{~Hz}, \beta)$ \\
\hline \multirow[t]{2}{*}{2} & 23.52 & $1.73(2 \mathrm{H}, \mathrm{m})$ & 23.5 & $1.68(1 \mathrm{H}, \mathrm{ddd}, \mathrm{J}=12.5,1.5 \mathrm{~Hz}, \beta)$ \\
\hline & & & & $1.74(1 \mathrm{H}, \mathrm{ddd}, \mathrm{J}=13,4 \mathrm{~Hz}, \alpha)$ \\
\hline 3 & 80.13 & $4.57(1 \mathrm{H}, \mathrm{dd}, \mathrm{J}=11.2,4.4 \mathrm{~Hz})$ & 80.2 & $4.55(1 \mathrm{H}, \mathrm{dd}, \mathrm{J}=11.5,4.5 \mathrm{~Hz}, \alpha)$ \\
\hline 4 & 37.63 & - & 37.7 & - \\
\hline 5 & 49.28 & $1.48(1 \mathrm{H}, \mathrm{dd}, \mathrm{J}=11.6,5.2 \mathrm{~Hz})$ & 49.4 & $1.48(1 \mathrm{H}, \mathrm{dd}, \mathrm{J}=10.5,4.5 \mathrm{~Hz})$ \\
\hline \multirow[t]{2}{*}{6} & 24.65 & $2.22(1 \mathrm{H}, \mathrm{td}, \mathrm{J}=11.6,4 \mathrm{~Hz})$ & 24.7 & $2.22(1 \mathrm{H}, \mathrm{ddq}, \mathrm{J}=12.0,3.5,1.5 \mathrm{~Hz}, \beta)$ \\
\hline & & $2.45(1 \mathrm{H}, \mathrm{qd}, 20,4,8.8 \mathrm{~Hz})$ & & $2.44(1 \mathrm{H}, \mathrm{dq}, \mathrm{J}=20,5,4.0 \mathrm{~Hz}, \alpha)$ \\
\hline 7 & 135.82 & $6.9(1 \mathrm{H}, \mathrm{q}, \mathrm{J}=3.2 \mathrm{~Hz})$ & 135.7 & $6.89(1 \mathrm{H}, \mathrm{q}, \mathrm{J}=3.5 \mathrm{~Hz})$ \\
\hline 8 & 127.16 & - & 127.2 & - \\
\hline 9 & 50.57 & $2.82(1 \mathrm{H}, \mathrm{m})$ & 50.6 & $2.82(1 \mathrm{H}, \mathrm{m})$ \\
\hline 10 & 34.01 & - & 34.1 & - \\
\hline 11 & 66.95 & $\begin{array}{l}4.05(1 \mathrm{H}, \mathrm{t}, \mathrm{J}=9.2 \mathrm{~Hz}) \\
4.41(1 \mathrm{H}, \mathrm{t}, \mathrm{J}=9.2 \mathrm{~Hz})\end{array}$ & 66.9 & $\begin{array}{l}4.05(1 \mathrm{H}, \mathrm{t}, \mathrm{J}=9.0 \mathrm{~Hz}, \beta) \\
4.41(1 \mathrm{H}, \mathrm{t}, \mathrm{J}=9.0 \mathrm{~Hz}, \alpha)\end{array}$ \\
\hline 12 & 169.81 & - & 169.7 & - \\
\hline 13 & 27.80 & $\begin{array}{l}0.93(3 \mathrm{H}, \mathrm{s}) \\
(3 \mathrm{H}, \mathrm{s}, \mathrm{H}-13)\end{array}$ & 27.6 & $\begin{array}{l}0.94(3 \mathrm{H}, \mathrm{s}) \\
(3 \mathrm{H}, \mathrm{s}, \mathrm{H}-13)\end{array}$ \\
\hline 14 & 15.99 & $1.00(3 \mathrm{H}, \mathrm{s})$ & 15.9 & $1.00(3 \mathrm{H}, \mathrm{s})$ \\
\hline 15 & 13.49 & $0.84(3 \mathrm{H}, \mathrm{s})$ & 13.5 & $0.84(3 \mathrm{H}, \mathrm{s})$ \\
\hline 16 & 21.23 & $2.08(3 \mathrm{H}, \mathrm{s})$ & 21.2 & $2.07(3 \mathrm{H}, \mathrm{s})$ \\
\hline 17 & 170.79 & - & 170.7 & - \\
\hline
\end{tabular}


Based on the above spectroscopic data and in comparison with literature data (Wube et al., 2005), WU-2 is proposed to be $(+)$ cinnamolide-3 $\beta$-acetate $(\mathbf{8})$.
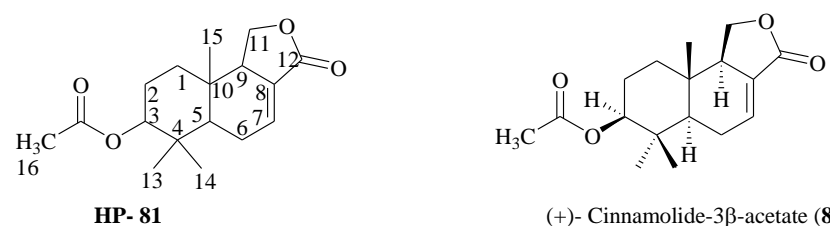

Figure 13. The structure of WU-2 and of cinnamolide-3 $\beta$-acetate (8)

\section{CONCLUSION}

Phytochemical investigation of the stem bark of Warburgia ugandensis Sprague (Canellaceae) afforded two bioactive sesquiterpenes namely WU-1 (ugandensidial) and WU-2 (cinnamolide-3 $\beta$-acetate) isolated from dichloromethane and chloroform extracts respectively. Identification of these compounds was based o the melting point, array of spectroscopic data (UV/Visible and NMR) and comparison of their spectroscopic data with reported literature values. The traditional medicinal use of this plant may be attributed to its high content of these bioactive constituents.

Acknowledgement: The author would to acknowledge Addis Ababa University for providing all the equipments and materials during this research work. Also special thanks to Haramaya University for their kind financial support.

Conflict of interest: The author declares that there are no conflicts of interest concerning the publication of this article.

\section{REFERENCES}

Butler, M.S. (2004). The Role of Natural Product Chemistry in Drug Discovery. J Nat Prod., 67(12) 2141-2153. DOI: 10.1021/np040106y

Dagne, E. (2009). Natural Database for Africa (NDA) On CDROM. Version1. Addis Ababa, Ethiopia. http://www.chemnetethiopia.com.

Dharani, N., Rukunga, G., Yenesew A., Mbora A., Mwaura L., Dawson I.; Jamnadass R. (2008). Common Antimalarial Trees and Shrubs of East Africa. $1^{\text {st }}$ edition. World Agro-forestry Centre: Nairobi, Kenya. ISBN: 978-92-9059-238-9. DOI: 10.1016/j.phytochem.2005.07.018

Drage, S., Mitter, B., Muchugi, A., Trols, A., Jamnadass, R. H., Sessitsch, A., Hadacek, F. (2014). Antimicrobial drimane sesquiterpenes and their effect on endophyte communities in the medical tree Warburgia ugandensis. Front Microbiol. 5(13). DOI: 10.3389/fmicb.2014.00013

Geyid, A., Abebe, D., Debella, A., Makonnen, Z., Aberre, F., Teka, F., Kebede, T., Urga, K., Yersaw, K., Biza, T., Mariam, B.H., Guta. M. (2005). Screening of some medicinal plants of Ethiopia for their anti-macrobial properties and chemical profiles. J. Ethnopharmacol, 97, 421-427. DOI: 10.1016/j.jep.2004.08.021

Gómez, G. S., Pelacho, A., Gené, A., Capell, T., Christou, P. (2007). The genetic Manipulation of Medicinal and Aromatic Plants. Plant Cell Rep.,26, 1689-1715.DOI: 10.1007/s00299007-0384-x

Karani, L. W., Tolo, F. M., Karanja, S.M., Khayeka, C. W. (2013). Safety and efficacy of Prunus africana and Warburgia ugandensis against induced asthma in BALB/c Mice. Eur. J. Med. Plants. 3(3) 345-368. DOI:10.9734/EJMP/2013/3669

Kioy, D., Gray, A. I., Waterman, P. G. (1990). A comparative study of the stem barks drimane sesquiterpenes and leaf volatile oils of $W$. ugandensis and $W$. stuhlmannii. Phytochemistry, 29(11) 3535-3538.DIO: 10.1016/00319422(90)85270-P

Maroyi, A. (2013). Warburgia salutaris (Bertol. f.) Chiov; A multi-use ethnomedicinal plant species. J. Med. Plant Res., 7(2) 53-60. DOI: 10.5897/JMPR12.1019

Maundu, P., Tengnas, B. (2005). Useful Trees and Shrubs for Kenya. World Agroforestry Centre Eastern and Central Africa Regional Programme (ICRAF-ECA), Nairobi, Kenya. ISBN 9966-70-8.

Mbwambo, Z. H., Erasto, P., Innocent, E., Masimba P. J. (2009). Antimicrobial and cytotoxic activities of fresh leaf extracts of Warburgia ugandensis. Tanzan. J. Health Res, 11 (2) 75-78. http://dx.doi.org/10.4314/thrb.v11i2.45205

Mohammed G. R., Extraction, Isolation and Characterization of Natural Products from Medicinal Plants. International Journal of Basic Sciences and Applied Computing (IJBSAC)ISSN: 2394-367X, 2 (6) 2018

Muchugi, A., Muluvi, G. M., Kindt, R., Kadu, C. A. C., Simons, A. J., Jamnadass, R.H. (2008). Genetic structuring of important medicinal species of genus Warburgiaas revealed by AFLP analysis. Tree Genet Genomes, 4(4) 787-795. DOI: 10.1007/s11295-008-0151-3

Ngure, P. K., Tonui, W. K., Ingonga. J., Mutai, Ch., Kigondu, E., Ng'ang'a, Z., Rukunga, G., Kimutai, A. (2009). In vitro antileishmanial activity of extracts of Warburgia ugandensis (Canellaceae), a Kenyan medicinal plant. J. Med. Plants Res., 3(2)61-66. DOI 10.3923/rjmp.2009.61.68

Rabe, T., Van Staden, J. (2000). Isolation of an antibacterial sesquiterpenoid from Warburgia salutaris. $J$. Ethnopharmacol., 73(1-2) 171-174. DOI:10.1016/s03788741(00)00293-2

Rajab, M.S., Ndegwa, J.M. (2000). 11 $\alpha$-Hydroxymuzigadiolide, a novel drimane sesquiterpene from the stem barks of Warburgia ugandensis. Bull. Chem. Soc. Ethiop. 14(1) 45-49. ISSN 1011-3294

Rukutt, J. K., Ngigi, A. N., Ndalut, P. K. (2005). Evaluation of natural products as possible alternatives to methyl bromide in soil fumigation. J. Agri. Sci. Tech, 7(1) 41-52. DOI: 10.1016/j.phymed.2003.08.005

Saiprasanna, B., Manohar, B.S., Roja, R. Y., Prasanta, K. C., Rajeshree, P. (2012). Phytochemical investigation and study on antioxidant properties of Ocimumcanum hydro-alcoholic leaf extracts. J. Drug Deliv. Ther., 2(4) 122 -128. DOI:10.22270/jddt.v2i4.198

Sasidharan S., Chen Y., Saravanan D., Sundram K. M., Yoga L. L. (2011). Extraction, isolation and characterization of bioactive compounds from plants' extracts. Afr J Tradit Complement Altern Med., 8(1) 1-10, DOI: 10.4314/ajtcam.v8i1.60483. 
Sukirtha, K., Growther, L. (2012). Antibacterial, antifungal and phytochemical analysis of selected medicinal plants.J. Nat. Prod. Plant Resour., 2(6) 644-648. (http://scholarsresearchlibrary.com/archive.html)

Wube, A. A., Bucar, F., Gibbons, S., Asres, K., Rattray, L., Croft, S.L. (2010). Antiprotozoal activity of drimane and coloratane sesquiterpenes towards Trypanosoma brucei rhodesiense and Plasmodium falciparum in vitro. Phytother Res., 24(10) 14681472. DOI: $10.1002 /$ ptr.3126
Wube, A. A., Bucar, F., Gibbons, S., Asres, K. (2005). Sesquiterpenes from Warburgia ugandensis and their antimycobacterial activity. Phytochemistry, 66(19) 23092315.

Xu, M., Litaudon, M., Krief, S., Martin, M., Kasenene, J., Kiremire, B., Dumontet, V., Guéritte, F. (2009). Ugandenial A, a new drimane-type sesquiterpenoid from Warburgia ugandensis. Molecules, 14(10) 3844-3850. DOI: 10.3390/molecules 14103844 